\section{PARISITIZING BY BREWER'S BLACKBIRD?}

Of the four Warbling Vireo nests I discovered at Turtle Lake this summer, only one was successful. All four nests were in birches, less than $200 \mathrm{ft}$. apart. The most interesting nest was located on a steep slope in front of my cabin where I was able to observe the birds daily from my balcony with binoculars. We had photographed the bird on the nest on 3 July, so when we returned 10 July we expected to see babies. On 9 July, a horde of blackbirds had descended on the "point" (our peninsula) and harassed and tormented our wee birds. On 11 July we noted no activity around the nest so I investigated. Instead of vireos we found a single brown blotched egg (chipped). I removed it and returned to Saskatoon to consult with Bernie Gollop who suggested it might be a Brewer's Blackbird egg. This was later confirmed by Jim Slimmon.

Of note: The flock of blackbirds consisted of immature and females of Brewer's, Yellow-headed and Redwinged Blackbirds. I had not examined the contents of the Vireo nest earlier because we had already had two nests vandalized (possibly by red squirrels) and hoped to prevent a recurrence. Warbling Vireos nest regularly on Indian Point, but they were in greater numbers this year, possibly because forest tent caterpillars, while denuding most deciduous trees for 20 miles around in June, had not touched our point. Muriel Carlson, 406 Spruce Drive, Saskatoon, Saskatchewan, S7N 2N4.

\section{PROTECTING WHOOPING CRANES}

In October 1979, a pair of Whooping Cranes with one chick stopped at a shallow lake north of Unity, Saskatchewan. The juvenile was banded (red left leg, blue-whiteblue right leg). The goose hunting season was on and there was a big flock of white geese on the same lake. When they were disturbed by hunters, the white cranes flew up too.

The reason that I write this letter is to thank the land owner who was really interested and helpful. . . . He posted all his land with signs. The result was that both adults and juveniles arrived safely in Aransas on 5 October 1979. Many thanks to Mr. and Mrs. Slater of Unity (N1/21-41-23 W3), Ken Smith, conservation officer of North Battleford, and Ernie Kuyt, CWS, Edmonton. - Hans de Vogel, Neilburg, Saskatchewan, SOM $2 \mathrm{CO}$.

\section{OWL BANDING IN SASKATCHEWAN}

If you've ever gone owl-banding, you'll think it is a very remarkable, even risky, thing to do. And that is exactly what it is. To go out and see an owl get banded is fun. When I went owl banding with Dr. Houston, we only found one little owl. We helped band it, though. The band has to be fairly large in order to get it around the owl's foot. The owl we banded had recently fallen out of its nest. Once it was banded properly, the owl was 
brought back up to the nest on a rope with a stick on it so that the owl was not injured in any way. Owl banding in Saskatchewan should increase so that people know what to do when they come across a dead owl, or a little owl which has fallen out of its nest. - Tony Hrynewich, Grade 5, Dixon Lake School, Crystal Springs, Saskatchewan, SOK $1 \mathrm{AO}$.

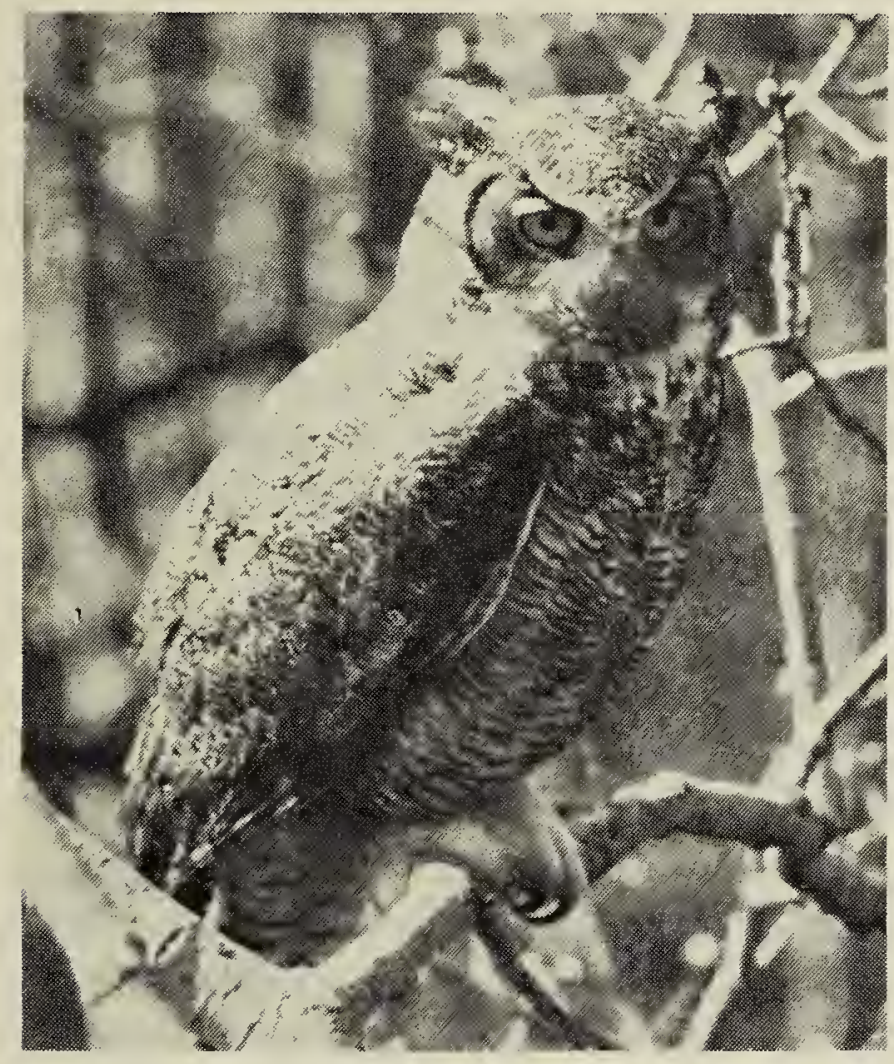

Great Horned OwI

Lorne Scott

\section{MORE JACK RABBITS}

I was pleased to see two articles in the June 1980 issue of the Blue Jay on the concentration of white-tailed jack rabbits by Fred $W$. Lahrman and Robert Kreba. I have seen large concentrations of these rabbits during the winters of 1978-79 and 1979-80.

It has been my duty, painful at times, to have to exercise two dogs, one a German Short-haired Pointer and the other a Miniature Poodle. They are known as "The Odd Couple". I exercise them by taking them out in the country and walking with them on some untravelled road.
In the winter, when the snow is deep enough, I put on a pair of snowshoes and we leave the road.

One of the favourite places is on land belonging to the Experimental Farm, but to the south and west of the Saskatchewan Power Corporation Transformers, south-east of Regina. On this land there are two long hedges, which have been planted. These hedges seem to provide the jack rabbits with shelter.

The dogs have a good time attempting to chase the jack rabbits. The rabbits do not seem to mind as the chances of one of them being caught are minimal.

The largest number I have seen, at one time, was 22 and 40 in one afternoon, but you can be sure of seeing a good many on any afternoon. Although there is a concentration of rabbits, I have not seen a concentration of predators. The pointer, however, frequently finds portions of jack rabbits which have fallen prey to some bird or animal. These she carefully buries in the snow, to be exhumed the next time we cover the territory and re-buried in a different spot.

I would like to know if anyone has an explanation for this concentration. The hedges do provide shelter and this is increased by the drifts of snow, which pile up against the hedges. There would appear to be ample food in the stubble fields surrounding the hedges and as far as I can see the bark on the shrubs has not been eaten. They may not like this particular type of bark. There is no aspen in the area.

As if to contradict the shelter idea, I am told that there are many jack rabbits just east of the elevators at Rowatt, in open country. - J. W. Jackson, 233 Frontenac Drive, Regina, Saskatchewan, S4S 4L2. 